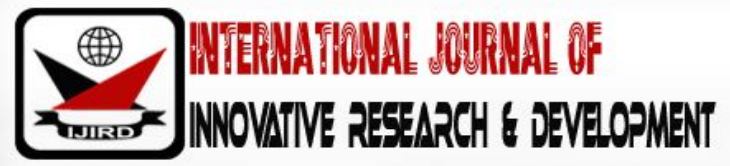

ISSN 2278 - 0211 (Online)

\section{Analysis of the Influence of Macro Economic Factors against JCI Return in Indonesia Stock Exchange}

\begin{tabular}{|c|}
\hline $\begin{array}{c}\text { Said Djamaluddin } \\
\text { Lecturer, MercuBuana University, Jakarta, Indonesia } \\
\text { Muhammad Rizki }\end{array}$ \\
Alumni, MercuBuana University, Jakarta, Indonesia \\
Apollo \\
Lecturer, MercuBuana University, Jakarta, Indonesia \\
\hline
\end{tabular}

\begin{abstract}
:
The study aims to examine how the influence of macroeconomic factors by using the variable exchange rates, interest rates, foreign exchange reserves and the price of Indonesian crude oil to JCI return. Information on interest rates, exchange rates and foreign exchange reserves of Indonesia obtained from Bank Indonesia, while the price of Indonesian crude oil taken from the Ministry of Energy and Mineral Resources. JCI data source comes from IDX Monthly Statistics report in the Indonesia Stock Exchange with a total sample of 96 data. Data analysis techniques in this study using multiple regression analysis. Based on the results of the study showed that the movement of the exchange rate, interest rate, foreign exchange reserves and crude oil prices Indonesia jointly influence to JCI return. The results also showed that the movement of the exchange rate and interest rates significantly negative influence to JCI return while the growth of foreign exchange reserves and oil price movements Indonesia significant positive effect on JCI return.
\end{abstract}

Keywords: Exchange rates, interest rates, foreign exchange reserves, Indonesian crude oil Price,JCI return

\section{Introduction}

Change the constellation of the global economy since the crisis of 2008 and then feels so vast and profound has raised a range of increasingly complex new challenges in the management of macroeconomic stability. Indonesia's economy for the year 2015 is exposed to a series of external shocks in the global economy that impact in Indonesia either through financial or trade lines. At the time of Vice President Jusuf Kalla close stock trading the last day of the period of 2015, the composite stock price index (JCI) rectified 12.13\% throughout this year and became the top five worst capital market in Asia Pacific (Sukirno, 2015).

Return the JCI movement showed that the capital gains obtained by the investor is getting smaller from year to year. Basically, there are two advantages that accrue to investors by buying or owning the stock i.e. dividends and capital gains. A dividend is a division of advantage given the company and the resulting profits come from corporations. The dividend is given after the approval of the shareholders in general meeting. Capital gains i.e. a condition where investors sell the stock is higher than the purchase price. A capital gain is the difference between the buying price and the selling price. Capital gains are formed by the existing stock trading activities in the secondary market. The JCI movement return from year to year are likely to provide the growth that's getting a bit as shown in Figure 1.

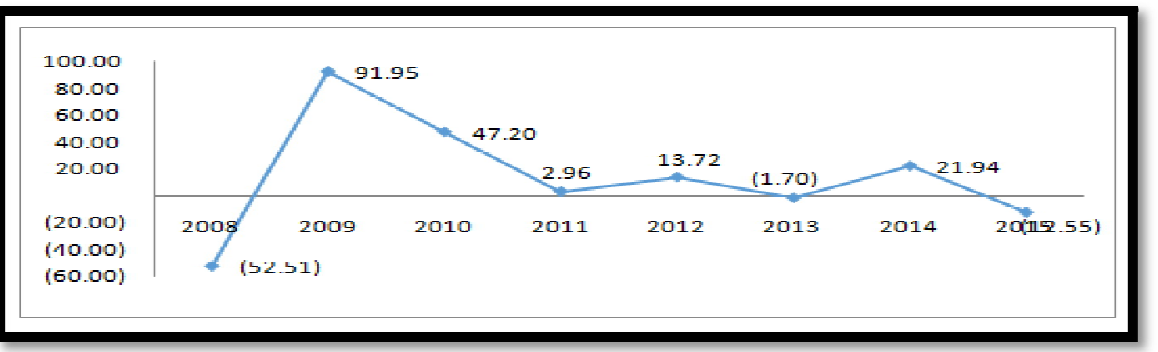

Figure 1: Graph the Movement Return JCI 2008-2015

Source: IDX Statistics 2008-2015 
Indonesia's macroeconomic indicators consist of per capita GDP (US dollar), total private debt (net private), net foreign exchange reserve (USD billion), rupiah exchange rate against US dollar (average), Interest Rate of Bank Indonesia (\%), consumer price index (average), and crude oil price of Indonesia (US \$ per barrel) (World Bank, 2016). The growth of the company that drives the Indonesian economy is influenced by the rupiah exchange rate against the US dollar, the interest rate of Bank Indonesia and of course the price of Indonesian crude oil, while the important indicator that shows economic strength a. country is a foreign exchange reserve.

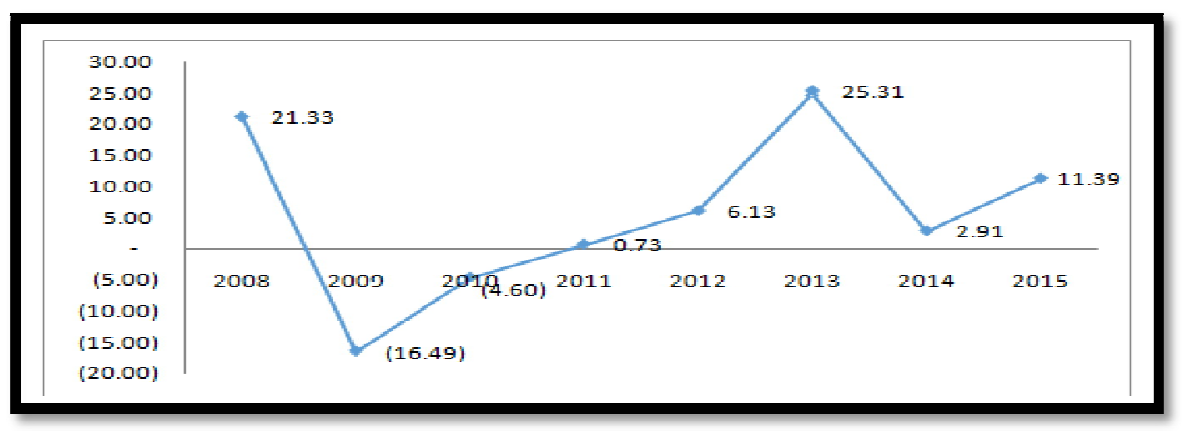

Figure 2: Graph the Movement of Exchange Rates 2008-2015

Source: Bank Indonesia 2008-2015

The exchange rate of the rupiah against the United States dollar at position 31 December 2015 RP 2,440 rectified from the starting position, January 31, 2009 to RP 13,795. Changes in currency exchange rates can give a positive and negative impact to the company. While the exchange rate of the rupiah depreciate against the United States dollar, to the company or companies that import has debts in the form of the United States dollar, it can negatively affect, but for a company that got a receipt in the form of export companies such as United States dollars, it can positively impact.

A previous study entitled analysis of the influence of the rate of inflation, the exchange rate USD/ Idr, and SBI interest rate pegged to the composite stock price index to find the influence of the exchange rate USD/ Idr is negative significantly to JCI (Machmud and Wijanarko, 2013). Previous research on the other, entitled the Indian stock market and macroeconomic factors in current scenario generates a positive exchange rate effect that significant BSE Sensex and Nifty CNX S\&P (Pooja Singh, 2014). Look at the graph of the movement of exchange rates 2008-2015, the exchange rate tends to show the influence of negativity to the return, such as JCI in 2009 return JCI increased but Exchange rates thus decreased.

The relative stability of the terjaganya macro that is reflected from the BI Rate adequate response in the control of inflation, the attainment of high economic growth, as well as foreign exchange reserves is still within the limits of safety. The BI Rate is the interest rate policy that reflects the attitude or stance of monetary policy is set by Bank Indonesia and announced to the public. For investors, the drop in interest rates of deposits will reduce the level of benefits that accrues when a fund invested in the form of deposits. But the decline in the credit interest rates will cause capital costs be small so that it can facilitate companies to obtain additional funds with a cheap cost to increase its productivity.

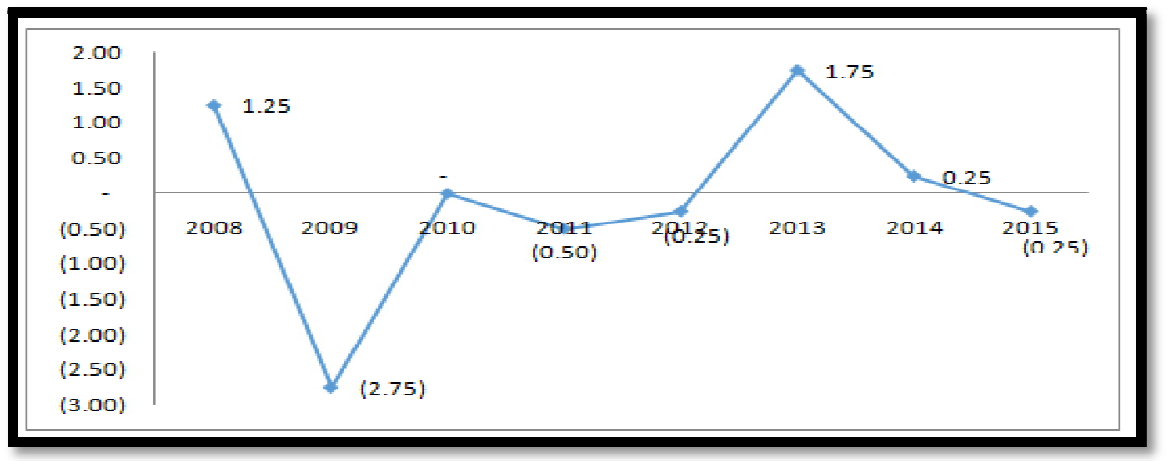

Figure 3: Graph the Movement of Interest Rates 2008-2015

Source: Bank Indonesia 2008-2015

A previous study entitled the influence of the BI rate, the fed's rate, and the rupiah exchange rate against the composite stock price index (JCI) produces a negative effect that the BI Rate significantly to jsx composite in BEI (Wijayaningsih, 1999). The results of the research hypothesis test entitled analysis of the influence of the inflation, interest rate and exchange rate BI rupiah against share price showed the positive effect of interest rates and stock prices significantly to (Kusuma, 2015). Based on the graph the movement of interest rates 2008-2015, interest rates look likely to be inversely 
proportional to return JCI as seen in 2009 JCI increased return but interest rates seen declining. Yet another thing to happen in 2011, along with JCI return decreased interest rates.

Indonesia foreign exchange reserves position late December 2015 recorded US \$105,9 billion, increased significantly from the position of the end of November 2015 100,2 billion US \$. The increase in foreign exchange reserves derived from foreign government loans of withdrawal, receipt of the results of oil and gas exports, and the issuance of government bonds globally is enough to cover the needs of foreign exchange, among other things, for the payment of the foreign debt of the Government as well as the use of foreign exchange in the framework of the stabilization of the exchange rate of rupiah in accordance with fundamentalnya. Understanding the foreign exchange reserves also helps us to know the big picture of the current economic cycle that will eventually have an impact on making investments.

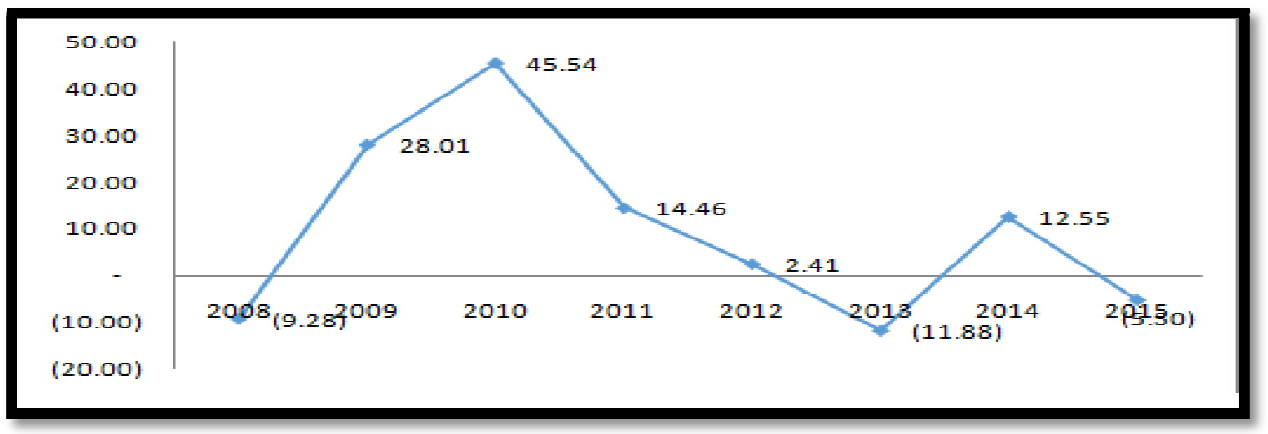

Figure 4: Graphthe Growth of Foreign Exchange Reserves 2008-2015

Source: Bank Indonesia 2008-2015

The results of previous research, entitled the influence of inflation, interest rates of bank Indonesia, world oil prices and foreign exchange reserves against the composite stock price index showed significant positive effect foreign exchange reserves against JCI (Mikial, 2014). Previous Penelian more with the title analysis of the influence of inflation, interest rates, foreign exchange reserves, the money supply, the exchange rate USD-IDR, towards the industrial sector's share price return basis chemistry in Indonesia resulted in the cement Subsector that the foreign exchange reserves and significant negative effect against the stock price (Sihombing, 2013). Chart the growth of foreign exchange reserves in 2008-2015 shows foreign exchange reserves tend to be positive with respect to return the JCI meaning if reserves increase then return JCI also increased.

The increase in world crude oil prices indirectly imposes on export and import sector of a country. For the petroleum exporting countries, the increase in the world crude oil price is an advantage for companies because of soaring oil prices made investors tend to invest their funds in various sectors of the oil and mining commodities. But if oil prices are going down investors tend to seek profits by selling their shares.

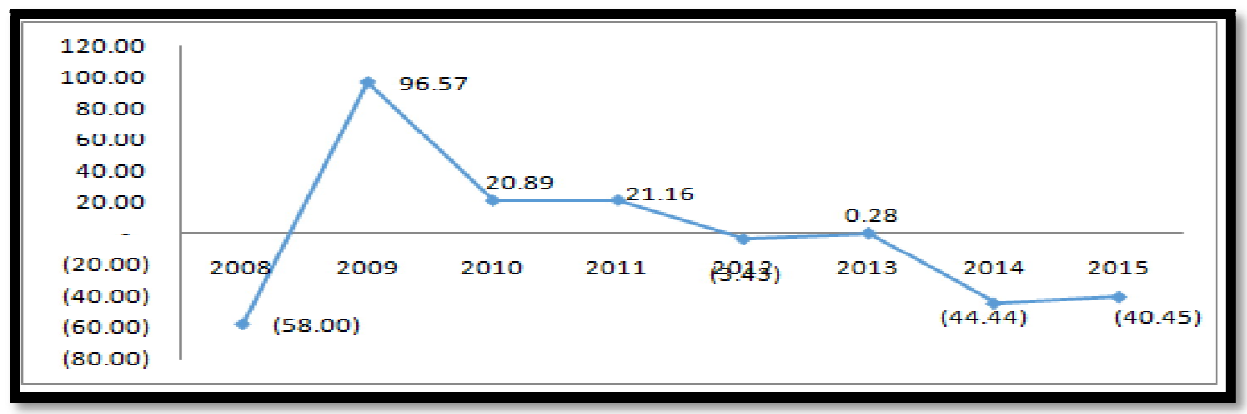

Figure 5 Graph the Movement Crude Oil Price 2008-2015

Source: Bank Indonesia 2008-2015

Macro economics discuss important issues that have always faced something The economy. When the macroeconomic conditions in a country experiencing the good changes that are the result of the study entitled analysis of the influence of fundamental macro and global price index against the JCI world oil prices suggest that the positive affect against JCI (Chabachib and Ardian, 2011). Research on the influence of macroeconomic variables and commodity prices against the composite stock price index in Indonesia produce positive effect world oil prices against the JCI (Lawrence, 2013). The results of previous research, entitled the influence of inflation, interest rates of bank Indonesia, world oil prices and foreign exchange reserves against the composite stock price index showed a negative effect oil prices significantly to JCI (Mikial, 2014). Crude oil 
price chart 2008-2015 looks crude oil prices are likely to be in line with the return movement of the JCI, namely the increasing price of crude oil will be followed increasing return JCI.

The existence of the phenomenon in which occurs the relationship between the independent variable and the dependent variable is the observed during 2008 - 2015 there are not in accordance with the theory, as well as the existence of a difference research results previously discussed about the variables that influence the composite stock price index. the difference between previous studies and the phenomenon has been revealed, the author is interested to take the discussion about the influence of macroeconomic analysis using variable exchange rates, interest rates, foreign exchange reserves of crude oil prices and Indonesia's response to the JCI.

The intent of the research was to analyze the effect of movements in exchange rates, interest rates, foreign exchange reserves and crude oil prices Indonesia simultaneously and partial towards return JCI in semester II of 2008-semester II of 2016. The purpose of the study is to know the influence of the movement of exchange rates, interest rates, foreign exchange reserves and crude oil prices Indonesia simultaneously and partial towards return JCI in semester II of 2008-semester II of 2016.

\section{Literature Review}

Macro focusing on economic behavior and economic policies can affect the levels of consumption and investment, trade and balance of payments of a country. In summary, it can be said that the macro economy is concerned the interaction between labor, turnover goods, and economic assets that led to the trading activities of the individual or the State. A country's macroeconomic condition is one of the factors that can affect the performance of the existing companies in the country.

Macro economics discuss important issues that have always faced something the economy. When the macroeconomic conditions in a country experiencing a change in either positive or negative, investors will mengkalkulasikan impact on the company's performance in the future, then take the decision to buy or sell shares of the company in question. Sell and buy this action will result in the occurrence of stock price changes and will ultimately affect the index of capital market in the country. Macroeconomic indicators, among others, Indonesia consists of per capita GDP (us dollars), the gross foreign exchange reserves (USD billion), exchange rate of the rupiah against the United States dollar (average), Bank Indonesia interest rate (\%), the consumer price index (average), and the Indonesia crude oil price (US \$ per barrel) (The World Bank, 2016). As for the macroeconomic indicators of Indonesia that is used in this study with attention to dynamic data, among others, exchange rates, interest rates, foreign exchange reserves and crude oil prices Indonesia.

The exchange rate is the price in the country of foreign money. A rise in the exchange rate is called depreciation or diminution of the value of the domestic currency in relation to foreign currencies, while the drop in the exchange rate appreciation or called the increase in value of the domestic currency in relation to foreign currencies. Price describes how much a currency must be exchanged to obtain one unit of another currency. Other terms of the exchange ratio is the exchange rate or also called the foreign exchange rate. (Pure, 2016:265).

Anjloknya commodity prices will impact badly on performance of exports and lower foreign currency supply sourced from export proceeds. The increase in imports due to strong domestic demand also needs foreign currency. The pressure of demand for Foreign Exchange increased if there is a flow of foreign stock portfolio funds exit. Decline in the supply of foreign currency that accompanied the high demand for foreign currency led to the high pressure of the depreciation of the exchange rate.

The interest rate is the annual interest payment of a loan, in the form of a percentage of the loan obtained from the amount of interest earned each year divided by the amount of the loan. The interest rate is the price of the loan. As for the interest rates used in this study BI Rate is the interest rate policy that reflects the attitude or stance of monetary policy is set by bank Indonesia and announced to the public. BI Rate announced by the Board of Governors of Bank Indonesia Board of Governors each meeting monthly and implemented on monetary operations performed Bank Indonesia through the management of liquidity (liquidity management) in the money market to achieve operational objectives of monetary policy. As for the function of interest rates, among others:

- As an attraction for the depositors who have more funds to be invested.

- The interest rate can be used as a monetary tool in order to control the supply and demand of money in circulation in an economy. For example, the Government supports the growth of a particular industry sector when companies from the industry will borrow funds, then the Government gives a lower interest rate than other sectors.

- The Government can make use of interest rates to control the money supply. This means, the Government can regulate the circulation of money within an economy.

The operational target of monetary policy is reflected in the development of interest rates on the interbank market Overnight ( $\mathrm{O} / \mathrm{N} \mathrm{PUAB}$ ). Movements in interest rates $\mathrm{PUAB}$ are expected to be followed by the developments in deposit interest rates, and in turn the banking credit interest rates. Bank Indonesia also takes into account other factors in the economy, in General will raise BI Rate if inflation forward estimated to exceed a predetermined target, instead of Bank Indonesia will lower the BI Rate in inflation ahead is estimated to be below the target that has been set.

Foreign exchange reserves are an important indicator that shows the strength of the economy of a country, i.e. the extent to which the country is able to finance the needs in his country. In addition, the foreign exchange reserves in a sufficient 
amount are one guarantee for the achievement of monetary and macroeconomic stability of a country (Ellen, 2016). Foreign exchange reserves will be closely related to a country's balance of payments.

Understand about this macro indicators, also helps us to know the big picture of the current economy cycle that ultimately will also have an impact on making investments. Official foreign exchange reserves Indonesia (Indonesian Official Reserve Assets) is the external assets to finance its balance of payments imbalance, does not include the inclusion of Bank Indonesia on the international financial institutions, the Bill to non-residents in non-convertible currencies, or bills in foreign exchange to the population. The position of foreign exchange reserves is usually said to be secure when it suffices import for 3 months. If the import is insufficient foreign exchange reserves during the time the minimum, then the condition is considered prone. In addition to the difficulty of importing goods that it needs from abroad, the foreign exchange reserves position prone also lowers the credibility of the country's currency.

The international price of crude oil, which is used in Indonesia known as ICP (Indonesian Crude-Oil Price) which is the base price of the crude oil that is used in the calculation and drafting of the state budget. ICP is used as oil price assumptions in the budget to determine the quantity of oil and gas energy subsidies, acceptance, and funds for oil (Handoko, 2014:53). The determination of the magnitude of the price of oil is very important considering how much oil prices influence on Division of production (lifting) between the contractor and the Government. Therefore, the Government is taking a role in the determination of the method of calculation of the Indonesia crude oil price (ICP). The determination of oil prices in the international market as we know it is a complex issue. ICP is set every month and are evaluated each semester according to the characteristics and quality.

The capital market is one of the economic instruments currently undergoing rapid development. Indonesia capital market structure consisting of various institutions or agencies who arranged systematically starting from the highest authority of the capital market, self-regulatory organization, as well as other parties that support and have a role in administering the activities of capital market transactions. It is inseparable from the development of investment activities lately caused the ease of investing, regulation, deregulation and free flow of information. Investment in fact will be the placement of the amount at this time with the hope to gain an advantage in the future (Halim, 2015:13). Generally differentiated into two investments, i.e. investments in financial assets and investments in real assets. Investments in financial assets carried out in the money market, for example, in the form of certificates of deposits, commercial paper, bonds and other money, or in the capital markets, for example in the form of stocks, bonds, warrants, options, and more.

Composite stock price index (JCI) was first introduced on April 1, 1983 as an indicator of price movement of stocks listed on the stock exchange. Today the basic calculation of the index is 10 August 1982 with a value of 100 . While the number of issuers listed at that time was as much as 13 issuers (Azis, 2015:339-340). The number of issuers listed on the Indonesia stock exchange was up 537 issuers per 28 September 2016. Along with the development and dynamics of the market, the JCI experience periods of up and down. The basis of calculation of the JCI is the sum of the market value of total shares recorded on August 10,1982. The amount is the total market value of shares of any listed product (except for the companies that are in a restructuring program) with prices in the BEI on this day.

JCI uses all the companies listed as components of the calculation of the index. In order for the JCI can describe a State of reasonable market, Indonesia stock exchange authorities issued and or does not incorporate one or more of the companies listed in the calculation of the JCI. The basis of the reasoning, among other things, if the number of shares the company recorded those owned by the public (free float) is relatively small while its market capitalization is large enough, so that changes to the listed company's share price could potentially affect the reasonableness of the JCI movement. JCI belongs to Indonesia stock exchange. Indonesia stock exchange is not responsible for products which are published by users who use JCI as a reference (benchmark).

Indonesia Stock Exchange also has some sectoral indices. All sect oral stock indices recorded in BEI classified into ten sectors, according to the classification of industries. Sectoral index IDX is an index of the JCI. All issues listed on the BEI were classified into ten sectors, according to predefined industry classification BEI. Components - components are listed on the Indonesia Stock Exchange there are 10 sectors include components which are: consumer goods, agriculture, manufacturing, misc industry, mining, infrastructure, trade, finance, property, dan basic industry.

The JCI is one of the key components that are used to monitor the world economy with the function as follows:

- An indicator of the direction of the market movement means the numbers that occur in the JCI be indicators of economic activity that are taking place in society, where the value of the JCI increase means the stock price increase is taking place that is generally caused by the strengthening economy, but conversely, if the value of the JCI declined that his stock price also is down and when the downturn took place drastically, the Government will issue a policy for economic stability in the country.

- Indicators of the level of Profit which means the index number that is unreadable in JCI may also be an indicator of profit that would be associated with the various types of investment banking as well as the economy. The higher the index value, generally the advantages can also be increased.

- Benchmark Portfolio Performance which means when there is a consumer banking as well as investors who infuse capital in the form of bonds, the index measuring average JCI into value to determine the appropriate transaction strategy so that the concerned investors avoid losses. 
Earlier research conducted by Chabachib and Ardian in 2011 that result that the SBI interest rates and oil prices, the exchange rate of rupiah, the influential simultaneously against the JCI. Kewal research in 2012 which is described that the SBI interest rates, the rupiah exchange rate and the simultaneous effect on JCI in BEI. Similarly, with Lawrence in 2013 which States that collectively oil prices and interest rates in SBI effect significantly to the JCI in the period 2009-2012. The research of Msy Mikial from 2014 showed that interest rates on Bank Indonesia, world oil prices, and foreign exchange reserves have no effect against the JCI.

Based on previous research, then the framework of thought research was described as follows:

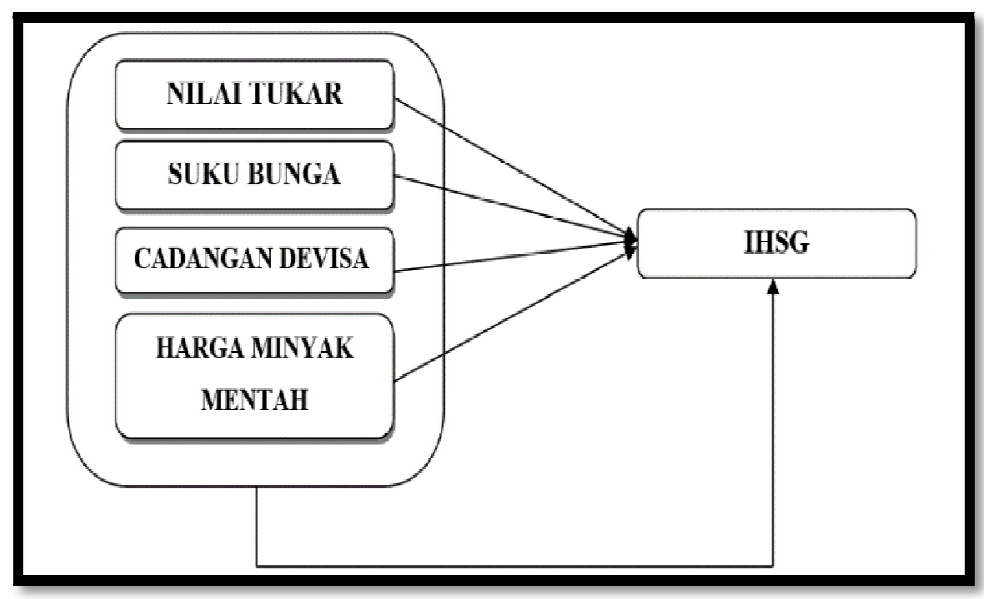

Figure 6: the Framework of Thought

IDR (Rupiah) exchange rate effect significantly negatively to JCI (Chabachib and Ardian, 2011). Exchange rates are partially significant negative effect against the return of large capitalization stocks (Halim, 2013). The exchange rate effect negatively and significantly to JCI variables (Divianto, 2013). Exchange rates affect the transaction activities of the company are mainly companies that depend on imports and oriented on foreign markets. Hypothesis $\mathrm{H} 1$ taken in this study, namely: H1: Presumed negative effect exchange rate significantly to return the JCI.

An SBI interest rate effect significantly negatively to JCI (Chabachib and Ardian, 2011). SBI interest rate effect negatively and significantly to JCI variables (Divianto, 2013). The negative effect of interest rates significantly to the Composite Index (Darwati and Nanda, 2014). BI interest rates negative and significant effect against the composite stock price index (Mikial, 2014). BI Rate negative significant effect against the composite stock price Index in BEI (Wijayaningsih, 1999). Decrease credit interest rates will cause capital costs be small so that it can facilitate companies to obtain additional funds with a cheap cost to increase its productivity. Hypothesis $\mathrm{H} 2$ taken in this study, namely:

H2: Presumed negative effect interest rates significantly to return the JCI.

Foreign exchange reserves are positive and significant effect against the JCI (Mikial, 2014). Significant positive effect foreign exchange reserves against the composite stock price index (JCI) period 2002 - 2013 (Sari et al, 2001). Foreign exchange reserves will be closely related to a country's balance of payments. If a country's foreign exchange reserves are high, then the balance of payments surplus will be. It is this balance of payments surplus which makes investors more interested in investing in Indonesia so as to enhance the trading of shares in the capital market in the country and led to an increase in the stock price. Hypotheses $\mathrm{H} 3$ taken in this study, namely:

- H3: Allegedly influential positive reserves significantly to return the JCI.

World oil prices a positive effect against JCI (Chabachib and Ardian, 2011). Significant positive effect oil prices against the composite stock price Index in the period 2009-2012 (Lawrence, 2013). World oil prices take effect positive against the composite stock price index in the period 2008-2013 (Handiani, 2001). The increase in the price of crude oil is a great advantage for companies mining sectors due to soaring oil prices made investors tend to invest their funds in various mining sector as the underpinning the increase in JCI. Hypothesis H4 taken in this study, namely:

H4: Predictably positive effect oil prices significantly to return the JCI.

SBI interest rates and oil prices, the exchange rate of rupiah, the influential simultaneously against the JCI (Chabachib and Ardian, 2011). SBI interest rates, the rupiah exchange rate and the simultaneous effect on JCI in BEI (Kewal, 2012). Together in oil prices and interest rates in SBI effect significantly to composite stock price index in the period 2009-2012 (Lawrence, 2013). BI rate and the exchange rate are jointly significant effect against the return of large capitalization stocks (Halim, 2013). A country's macroeconomic condition is one of the factors that can affect the performance of the existing companies in the country. Hypothesis H4 taken in this study, namely:

H5: Allegedly in exchange rates, interest rates, foreign exchange reserves and crude oil prices Indonesia together to return the JCI. 


\section{Research Methods}

Causal research design was used to prove the relationship between cause and effect of some variable. In this study data used is data that is quantitative, as revealed by the figures that show the values against variable it represents. The data used in this penelitian research, exchange rates, interest rates, foreign exchange reserves, Indonesia crude oil price and return the JCI.

Information exchange rates, interest rates, and foreign exchange reserves earned from Indonesia Bank Indonesia, while crude oil prices are taken from Indonesia's Ministry of energy and Mineral resources. Data source derived from the JCI reports IDX Monthly Statistics on the Indonesia stock exchange with a total sample of as many as 96 data. This research makes Exchange rates, interest rates, foreign exchange reserves and crude oil prices Indonesia semester II of 2008- semester I of 2016 to analyze the declined return JCI in 2008-2015.

\begin{tabular}{|c|c|c|}
\hline Variables & Measurement & Scale \\
\hline Exchange Rate & $\mathrm{R}=\frac{\text { Average Exchange Rate }_{\mathrm{t}}-\text { Average Exchange Rate }_{\mathrm{t}-1}}{\text { Average Exchange Rate } \mathrm{t}-1}$ & Ratio \\
\hline Interest Rate & $\mathrm{R}=$ Interest Rate $_{\mathrm{t}}-$ Interest Rate $_{\mathrm{t}-1}$ & Ratio \\
\hline $\begin{array}{l}\text { Foreign Exchange } \\
\text { Reserves }\end{array}$ & $\mathrm{R}=\frac{\text { Foreign Exchange Reserves }_{\mathrm{t}}-\text { Foreign Exchange Reserves }_{\mathrm{t}-1}}{\text { Foreign Exchange Reserves }}$ & Ratio \\
\hline Crude Oil Price & $\mathrm{R}=\frac{\text { Crude Oil Price }_{t}-\text { Crude Oil Price }_{t-1}}{\text { Crude Oil Price }}$ & Ratio \\
\hline JCI & 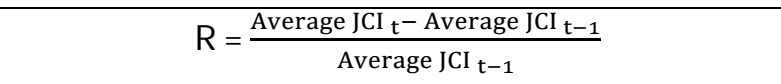 & Ratio \\
\hline
\end{tabular}

Table 1

Research Variables

Technique of data analysis in this study using multiple regression analysis. In order to test the strength of the free variables (Exchange rates, interest rates, foreign exchange reserves and crude oil prices Indonesia) against variables bound (JCI return) then in this study used multiple regression analysis with quadratic equations by the smallest basic model as follows:

$\mathrm{Y}=\mathrm{a}+\mathrm{b} 1 \mathrm{X} 1+\mathrm{b} 2 \mathrm{X} 2+\mathrm{b} 3 \mathrm{X} 3+\mathrm{b} 4 \mathrm{X} 4$

Description:

Y = Return JCI

$\mathrm{a}=$ Constant

$\mathrm{b}=$ Regression coefficient

$\mathrm{X} 1$ = The movement of exchange rates

$\mathrm{X} 2=$ The movement of interest rates

$\mathrm{X} 3=$ The growth of foreign exchange reserves

$\mathrm{X} 4=$ The price movement of crude oil Indonesia

As for the analysis tools is used multiple regression analysis by doing a classic assumption test first. The data used are secondary data, then to determine the accuracy of the model testing needs to be done on some classic assumptions is used, among other things test the normality, multicollinearity, heteroskedastisitas and autocorrelation.

Normality tests are used to test whether the regression model in both the independent variable or dependent variable has a normal distribution of the data or not. The good regression model is that it has a normal distribution of the data or close to normal. Multicollinearity test aimed at testing whether the regression model has found the existence of a correlation between independent variables. Good regression models should not happen correlation among variables. Test heteroskedastisitas aims to test whether the model regression residual variance inequality occurs from one observation to another observation. If the residual variance from one observation to another observation that remains, it is called homoskedastisitas. A good model is the homoskedastisitas. Autocorrelation test aimed at testing whether in a linear regression model, there is a correlation between the error of a bully on the data period $t$ with error bullies in the period $t-1$. Good regression model is a regression that is free of autocorrelation.

The next test of the hypothesis test, the coefficient of determination (R2) measures how far the capability model in explaining the variation of the dependent variable. The value of the coefficient of determination is between zero and one. The value of R2 that small means the ability of the independent variable in the dependent variables explaining the very limited. $F$ 
test or ANOVA test basically indicate whether all the variables included in the independent model of influence simultaneously against all the dependent variables. Statistical tests t basically shows how far the influence of one independent variable explain variation in partially dependent variables.

\section{Results and Discussion}

Normality test results it can be concluded that all of the variables used in this study, namely, JCI, exchange rates, interest rates, foreign exchange reserves and crude oil prices Indonesia have significance level above 0.05. Means the data used in this study have a normal distribution and shows that the regression model is worthy to wear due to meet the assumptions of normality.

Multicollinearity test results showed that all the independent variable of the regression model is not there is Multicollinearity is indicated by the value of the tolerance of all variables is greater than 0.10 and VIF all variables smaller than 10. This indicates that the regression model is worth to use because there are no variables that are experiencing multicollinearity.

Based on the results of the test heteroskedastisitas look that there are points that do not form a specific pattern or points that there is a spread above and below zero so that it could be inferred that the regression model in this study used do not experience heteroskedastisitas.

Autocorrelation test aimed at testing whether in a linear regression model, there is a correlation between the error of a bully on the data period t with error bullies in the period t-1. Good regression model is a regression that is free of autocorrelation. This research will use the durbin watson test for autocorrelation. SPSS output 23 results in table 5.4 Note that dW 1.604, then this value will be compared with the value of the table durbin watson with significance $5 \%$ total sample $\mathrm{n}=96$ and the number of independent variables for $\mathrm{k}=4$, then retrieved the value of $\mathrm{dU}=1,755$ and $\mathrm{dL}=1,582$. If the position of the $\mathrm{dL}<\mathrm{dW}<\mathrm{dU}=1.582<1.609<1.755$, then the test results are not convincing or inconclusive.

Durbin watson test also has a weakness when the value is between the dL and dU, then its decision could not have known autocorrelation autocorrelation what does not, so it needs to be done another test that is run test. Run test results in table 5.5 shows the significantly greater than 0.05 means that the residual value is not systematic or random.

Determination of coefficient of test results that the value adjusted $R$ square is of 0633 suggests that variations in the independent variables were able to explain the variation in the dependent variable $63.3 \%$, while the rest i.e. amounting to $22.8 \%$ explained by variables other than the independent variable. The value of the correlation coefficient (R) of 0796 suggests that the strong relationship between the independent variables the dependent variables against of 79,60\%. Standard Error of the Estimate is JCI 3.39 demonstrating the value that is much smaller than its standard deviation, then the regression model 5.47 nicer in the act as the Predictor JCI compared the average itself. From the results of the calculation of the value of the views that the ANOVA significance 0.000 and value is an F count of 39.278. The value of significance smaller than 0.05 regression models then can be used to predict the existence of the JCI or can be said to influence Exchange rates, interest rates, foreign exchange reserves and oil prices Indonesia simultaneously against the JCI.

Parametric statistical test results in the partial regression equation can form JCI $=0.825-0.806$ the exchange rate the interest rate +6.8080 .485 Reserves crude oil price 0.106 + Indonesia. The results of the research hypothesis influence Exchange rates, interest rates, foreign exchange reserves of crude oil prices and Indonesia's response to the JCI had partially been as follows:

- The results of the regression equation looks that the value of $t$-count of exchange rates was-5.617 with significance level of 0.000. It indicates that the negative effect of exchange rates and significantly to JCI.

- The results of the regression equation looks that count from the t-value interest rate is-3.226 with a level of significance of 0.002. It indicates that the negative effect and interest rates significantly to JCI.

- The results of the regression equation looks that the value of $t$-count of foreign exchange reserves was 4.432 with significance level of 0.000 . It showed that foreign exchange reserves are positive and significant effect against the JCI.

- The results of the regression equation looks that the value of $t$-count of Indonesia crude oil price was 2.631 with significance level of 0.010. It showed that the price of crude oil Indonesia positive and significant effect against the JCI. Hypothesis 1 proposed in this study is thought to negatively affect the exchange rate significantly to return the JCI. Based on the results of the calculation of the obtained hypothesis 1 was confirmed. These results indicate that the decline in the Rupiah exchange rate against the USD will encourage a rise in JCI. The results of this study support the Vejzagic and Mirza Hashem Zarafat in 2013 with the FTSE Bursa Malaysia on doing Hijrah Shariah Index as well as the research of Senen Machmud and Bambang Agus Wijanarko that same year with done against JCI.

Hypothesis 2 proposed in this study is thought to negatively affect interest rates significantly to return the JCI. Based on the results of the calculation of the obtained hypothesis 2 was confirmed. These results indicate that the decline in interest rates will encourage a rise in JCI. The results of this study support the research of h. m. Chabachib and Ardian Witjakson Supreme in 2011 and Divianto in 2013 which resulted that the SBI interest rate tiingkat effect negatively and significantly to JCI.

Hypothesis 3 proposed in this study was allegedly influencing positive reserves significantly to return the JCI. Based on the results of the calculation of the obtained hypothesis 3 was confirmed. These results suggest that an increase in foreign exchange reserves will support the improvement of JCI. The Research of Msy. Mikial in 2014 explained that the foreign 
exchange reserves of significant positive effect and research Erna Sari, Sri Wahyuningsih Pudji Hadiyati and in the same year produce research results that the foreign exchange reserves of significant positive effect against JCI period $2002-2013$ which supports the results of researchers. Other researchers, Jenny Sihombing and Hisar Pangaribuan in 2014 revealed that the foreign exchange reserves of the country have a positive influence significantly to return the shares.

Hypothesis 4 proposed in this study was allegedly influential Indonesia crude oil price significantly to positive return JCI. Based on the results of the calculations are obtained that hypothesis 4 was confirmed. The results showed that the price of crude oil Indonesia effect significantly to JCI. Research by Steven Lawrence Sugiarto in 2013, positive effect oil prices significantly to JCI. Another study done in New Zealand by Christopher Gan, Minsoo Lee Hwa Au Yong, Hua, Jun Zhang in 2006 also produce research results that significant positive effect oil prices against the return of shares NZSE40.

Hypothesis 5 proposed in this study was allegedly in exchange rates, interest rates, foreign exchange reserves and crude oil prices Indonesia together to return the JCI. Based on the results of the calculation of the obtained hypothesis 5 is proven. The results of this research are supported by previous studies by other research, antra Chabachib and Ardian in 2011 that result that the SBI interest rates and oil prices, the exchange rate of rupiah, the influential simultaneously against the JCI. Kewal research in 2012 which is described that the SBI interest rates, the rupiah exchange rate and the simultaneous effect on JCI in BEI. Similarly, with Lawrence in 2013 which States that collectively oil prices and interest rates in SBI effect significantly to the JCI in the period 2009-2012. The research of Msy Mikial from 2014 showed that interest rates on Bank Indonesia, world oil prices, and foreign exchange reserves have no effect against the JCI.

\section{Conclusion}

Based on the results of data analysis and discussion has been done, then it can be summed up as follows:

- The results of the study showed that the movement of the exchange rate effect is negative and significantly to return the JCI. This proves the hypothesis that the negative effect of exchange rates and significantly to return the JCI.

- The results of the study showed that the movement of interest rates negative and significant effect against return JCI. Calculation of the researchers have proved the hypothesis that interest rates are negative and significant effect against return JCI.

- The results of the study showed that the growth of foreign exchange reserves and significant positive effect against return JCI. This proves the hypothesis that positive and influential foreign exchange reserves significantly to return the JCI.

- The results of the study showed that Indonesia's oil price movement positive and significant effect against return JCI. Calculation of the researchers have proved the hypothesis of influential positive Indonesia oil prices and significantly to return the JCI.

- The movement of exchange rates, interest rates, foreign exchange reserves and crude oil prices Indonesia together to return the JCI is the result of research that proves the hypothesis is proven.

Based on the results of the analysis and the conclusion which has been described previously, the advice that can be expressed as follows:

- For investors being able to serve as an overview in the purchase of shares of public companies by looking at return the JCI is an indicator of share prices on the Indonesia stock exchange. Investors are expected to buy shares by looking at the performance of the company's stock and its effects on exchange rates, interest rates, foreign exchange reserves and crude oil prices Indonesia so as to define and implement a strategy for trading in the capital markets.

- For the Government so that it can serve as an indicator to increase exports and control imports of merchandise, conduct cooperation with other countries, and consideration of the Government in taking the policies to be taken with respect to the impact of movements in exchange rates, interest rates, foreign exchange reserves and crude oil prices Indonesia against return JCI in Indonesia stock exchange.

- For the next researcher, the results of this research can be used as a basis and can also be developed more extensively by taking the economic factors that others, in addition to exchange rates, interest rates, foreign exchange reserves and crude oil prices Indonesia, for example, gross domestic Income (GDP), consumer price index (CPI) and government debt.

\section{References}

i. Azis, Musdalifah, Sri Mintarti, dan Maryam Nadir. (2015). Manajemen Investasi: Fundamental, Teknikal, Perilaku Investor dan Return Saham. Deepublish. Sleman.

ii. Chabachib, H. M. dan Ardian Agung Witjaksono. (2011). "Analisis Pengaruh Fundamental Makro dan Indeks Harga Global terhadap IHSG”. Karisma. Vol.5(2). Hal: 63-72.

iii. $\quad$ Darwati, Suli and Nanda Trio Santoso. (2014). "Pengaruh Perubahan Nilai Tukar, Suku Bunga, Harga Minyak Dunia dan Indeks Saham Dow Jones Terhadap Index Harga Saham Gabungan pada Pasar Modal di Negara-Negara ASEAN". In: The 7th NCFB and Doctoral Colloquium 2014 Towards a New Indonesia Business Architecture Sub Tema: Business And Economic Transformation Towards AEC 2015 Fakultas Bisnis dan Pascasarjana UKWMS. October, 30, 2014. Hal: 47-56. 
iv. [4]. Divianto. (2013). "Analisis Pengaruh Tingkat Inflasi, Tingkat Suku Bunga SBI, dan Nilai Kurs Dollar AS (USD) Terhadap Indeks Harga Saham Gabungan (IHSG) di Bursa Efek Indonesia". Jurnal Ekonomi dan Informasi Akuntansi (JENIUS). Vol 3 No 2. Hal: 165-197.

v. [5]. Halim, Abdul. (2015). Analisis Investasi di Aset Keuangan. Mitra Wacana Media. Jakarta.

vi. [6]. Halim, Livia. (2013). "Pengaruh Makro Ekonomi terhadap Return Saham Kapitalisasi Besar di Bursa Efek Indonesia". Finesta. Vol 1 No 2. Hal: 108-113.

vii. [7]. Handiani, Sylvia. (2014). "Pengaruh Harga Emas Dunia, Harga Minyak Dunia dan Nilai Tukar Dolar Amerika/ Rupiah Terhadap Indeks Harga Saham Gabungan Pada Periode 2008-2013”. E-Journal Graduate Unpar Part A - Economics. Vol 1 No 1. Hal: 85-93.

viii. [8]. Handoko, Rudi.(2014). "Model Proyeksi Harga Minyak Mentah Indonesia (ICP) Bulanan dengan Metode Arima". Kajian Ekonomi dan Keuangan. Volume 18, No.1, Hal 51-68.

ix. [9]. Kewal, Suramaya Suci. (2012). "Pengaruh inflasi, suku bunga, kurs, dan pertumbuhan PDB terhadap indeks harga saham gabungan". Jurnal Economia. Volume 8 Nomor 1. Hal: 53-64.

x. [10]. Kusuma, Franky Pranata Putra. (2015). "Analisis Pengaruh Inflasi, Suku Bunga BI Rate dan Nilai Tukar Rupiah Terhadap Harga Saham (Studi Empiris Pada Perusahaan Sektor Pertambangan Di BEI 2011-2013)”. Artikel Publikasi Ilmiah. Fakultas Ekonomi dan Bisnis. Universitas Muhammadiyah. Surakarta.

xi. [11]. Lawrence, Steven Sugiarto. (2013). "Pengaruh Variabel Makro Ekonomi dan Harga Komoditas Terhadap Indeks Harga Saham Gabungan Di Indonesia”. Finesta. Vol 1 No 2 (2013). Hal: 18-23.

xii. [12]. Machmud, Senen dan Bambang Agus Wijanarko. (2013). "Analisis Pengaruh Tingkat Inflasi, Nilai Tukar USD/Rupiah, dan Tingkat Suku Bunga SBI Terhadap Indek Harga Saham Gabungan". Jurnal Ekonomi, Bisnis \& Entrepreneurship. Vol. 7 No 1. Hal: 30-40.

xiii. [13]. Mikial Msy. (2014). "Pengaruh Inflasi, Suku Bunga Bank Indonesia, Harga Minyak Dunia dan Cadangan Devisa Terhadap Indeks Harga Saham Gabungan”. Jurnal Kompetitif Universitas Tridinanti Palembang. Vol. 3 No. 2 Edisi Juli Desember 2014. Hal: 1-13.

xiv. [14].Murni, Asfia. (2016). Ekonomika Makro Edisi Revisi. Refika Aditama. Jakarta.

xv. [15].Sari, Erna, Sri Wahyuningsih dan Pudji Hadiyati. (2014). "Analisis Pengaruh Tingkat Inflasi, Nilai Tukar Rupiah Terhadap Dollar AS, Tingkat Suku Bunga SBI dan Cadangan Devisa Terhadap Indeks Harga Saham Gabungan (IHSG) Periode Tahun 2002 - 2013". Jurnal Manajemen \& Bisnis Aliansi. Volume 9 Nomor 18 Desember 2014. Hal: 77-84.

xvi. [16].Sihombing, Jenny dan Hisar Pangaribuan. (2013)."Analisa Pengaruh Inflasi, Tingkat Suku Bunga, Cadangan Devisa, Uang Beredar, Kurs USD-IDR, Terhadap Return Harga Saham Sektor Industri Dasar Kimia Pada Subsektor Semen di Indonesia". Jurnal Ekonomi dan Bisnis. Volume 7 No.2. Hal: 58-75.

xvii. [17].Singh, Pooja.(2014)."Indian Stock Market And Macroeconomic Factors In Current Scenario". International Journal of Research in Business Management. Vol 2 Issue 11. Hal: 43-54.

xviii. [18].Sukirno. (2015). INDEKS BEI 30 Desember: IHSG Turun 12,13\% Sepanjang 2015. Wapres JK tutup bursa. http:/ / market.bisnis.com/ read/ 20151230/ 7/ 505872/ indeks-bei-30-desember-ihsg-turun-1213-sepanjang-2015.wapres-jk-tutup-bursa. (Diakses tanggal 04 September 2016).

xix. [19].The World Bank. (2016). Perkembangan Triwulanan Perekonomian Indonesia, Tangguh berkat reformasi, Juni 2016. Jakarta.

xx. [20]. Wijayaningsih, Ria, Sri Mangesti Rahayu, dan Muhammad Saifi. (2016). "Pengaruh BI Rate, Fed Rate, dan Kurs Rupiah Terhadap Indeks Harga Saham Gabungan (IHSG)”. Jurnal Administrasi Bisnis (JAB). Vol. 33 No 2 Hal: 69-75. 